This article was downloaded by: [University of Gent]

On: 12 March 2010

Access details: Access Details: [subscription number 918060656]

Publisher Routledge

Informa Ltd Registered in England and Wales Registered Number: 1072954 Registered office: Mortimer House, 3741 Mortimer Street, London W1T 3JH, UK

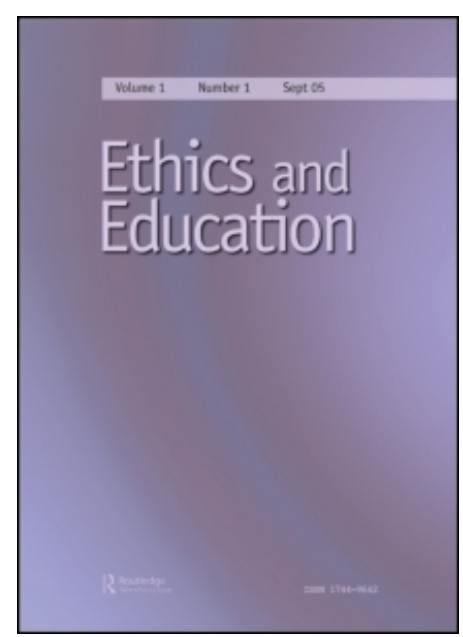

\title{
Ethics and Education
}

Publication details, including instructions for authors and subscription information:

http://www.informaworld.com/smpp/title content=t716100687

\section{Education, educational research, and the 'grammar' of understanding: a response to David Bridges}

Paul Smeyers ${ }^{\text {a }}$

${ }^{\text {a }}$ Ghent University and Katholieke Universiteit, Leuven, Belgium

Online publication date: 26 November 2009

To cite this Article Smeyers, Paul(2009) 'Education, educational research, and the 'grammar' of understanding: a response to David Bridges', Ethics and Education, 4: 2, 125 - 129

To link to this Article: DOI: $10.1080 / 17449640903326722$

URL: http://dx.doi.org/10.1080/17449640903326722

\section{PLEASE SCROLL DOWN FOR ARTICLE}

\footnotetext{
Full terms and conditions of use: http://www.informaworld.com/terms-and-conditions-of-access.pdf

This article may be used for research, teaching and private study purposes. Any substantial or systematic reproduction, re-distribution, re-selling, loan or sub-licensing, systematic supply or distribution in any form to anyone is expressly forbidden.

The publisher does not give any warranty express or implied or make any representation that the contents will be complete or accurate or up to date. The accuracy of any instructions, formulae and drug doses should be independently verified with primary sources. The publisher shall not be liable for any loss, actions, claims, proceedings, demand or costs or damages whatsoever or howsoever caused arising directly or indirectly in connection with or arising out of the use of this material.
} 


\title{
RESPONSE
}

\section{Education, educational research, and the 'grammar' of understanding: a response to David Bridges}

\author{
Paul Smeyers* \\ Ghent University and Katholieke Universiteit, Leuven, Belgium
}

It is a privilege to respond to such an insightful paper as the one presented to us by David Bridges. His central question: 'Is there something exclusive and superior about insider understanding which the outsider cannot understand?' is indeed not only crucial to the contexts he explicitly deals with, i.e. religious understanding, ethnographic research and intercultural understanding, but more general to all education. Bridges says that he identifies with Charlie Brown, who acknowledged that he does not even understand what he does not understand. But he also says that he will keep trying to understand. So what is it that Bridges in the end offers in terms of making sense of insider versus outsider understanding?

I think his answer comes down to the following five points:

1. we always stand in part as an insider and in part as an outsider in relation to another individual or community (in other words, the dichotomy between insider and outsider is unsustainable);

2. members of the same community will have different understandings of the community's experience, and any one individual will at different times and places and for different purposes construct different understandings of the same experience (in other words, we need to substitute a pluralistic notion of 'understandings' for a singular notion of 'understanding');

3. neither 'experience' nor 'practice' nor the so-called richer and fuller understanding of the insider warrants the supposed superiority of insider understanding;

4. instead, patience, persistence and hard graft, the phenomenographic turn, and in addition, imagination and empathy go a long way; and

5. finally, in some cases outsider understanding is superior, though this insight, Bridges argues, is slightly uncomfortable (here ethical and political issues demand our attention).

Thus, he concludes that there is nothing special about insider understanding that is not in principle at least accessible to an outsider.

It goes without saying, though, that it is worth reminding ourselves of the fact that 'in principle' does not imply that the outsider shares this knowledge just like that - something Bridges evidently will agree with. My short response to the paper Bridges offers is: 'Yes of course!' But it will all depend on what you mean by 'understanding'. It is the grammar of the concept itself that plays tricks on us. Before developing this issue, I will first deal with two of Bridges' substantial claims.

\footnotetext{
*Email: paul.smeyers@ped.kuleuven.be
} 
In dealing with the supposed superiority of insider understanding, understood as experience-based, Bridges quotes approving Tone Kvernbekk, who argues that it is highly improbable, bordering on impossible, that two people should have the same experience from participating in it. That may or may not be the case. But, more importantly, there is no way we can 'know' this, at least not in a Wittgensteinian sense. Bridges could therefore have argued in favour of a much stronger rejection of the 'experience-based argument'. If experience is necessary to understand someone else, this cannot refer to understand as knowledge, because we have no way in which we can check (and certainly not establish) whether someone else has the same or even the same kind of experience. But if that is so, and we still would want to argue that we can understand someone else, we have nothing we can rely on but what may be 'observed' by all of us, which makes the concept of experience being used here superfluous. (A similar point could be made about the knowledge of ourselves though this would invoke, among other things, the concept of 'consistency'.) Incidentally, from the Wittgensteinian stance to which Bridges refers, one would want to add that it belongs to the concept of experience (i.e. its grammar) that it evidently refers to a subject who is having this experience. Thus, though we can understand it, this does not equate to having that particular experience. A consequence thereof is, for example, that the expression 'You don't understand me' or 'You can't understand me' may equal to 'You are not a woman'.

One further point: the idea, touched on above, of what may be observed by all of us, evidently presupposes a context that makes sense for all involved in to the enterprise of observing and understanding. That includes for instance also 'having a body'. Thus the limit of our understanding is not so much 'experience based', as based on and in the human body and the form of life one shares with others. Peter Winch would use the expression 'what makes sense for us'. I think, and will return later to this issue, that the Wittgensteinian point already mentioned, because of its relation to practices (which may be observed), is more crucial than it appears at first sight. Incidentally, I will not pay attention to nor criticize Bridges' argument about the possible superiority of the outsider's understanding. But let me just note that I think that in psychoanalysis and Marxism (Bridges quotes Munz who uses the expression 'genuine' and 'real' knowledge), following Wittgenstein, something else is going on that in the work of Winch is identified by 'what it makes sense to say'. This may also be identified by labelling it a particular theoretical framework or even by drawing attention to the expressive function of language (such as in some rituals).

This brings us naturally to the second response that Bridges considers about the supposed superiority of insider understanding, i.e. in terms of 'practice'. And he quotes Wittgenstein: 'Practice gives the words their sense' (Wittgenstein 1980, 85e). In the context of religion, it is often noted, what matters is 'a change of life'. Here, I would want to take a different direction from Bridges and focus on the question in what sense taking part in a practice is an issue of understanding. This does not mean that I disagree with Bridges in as far as practice is no more helpful than experience in elucidating the claim of the alleged superiority of the insider perspective, but the concept of practice leads in my opinion to something different altogether. Bridges focuses on understanding in terms of knowledge. There is, however, a different concept of understanding that directs us towards - to remain in the Wittgensteinian frame of reference - 'knowing how to go on'. The ethnographer 
may or may not know this; the one who is part of a practice is by definition someone who knows how to go on (and evidently, she does go on in a particular way); denying this makes the concept of 'knowing how to go on' empty, evaporating in thin air. Now, if that is the case, relying on the concept of practice in order to claim the superiority of understanding (understood as knowledge of) misses the point completely of course - we should keep in mind Wittgenstein's insight that 'Interpretations themselves do not determine meaning' (Wittgenstein 1953, \# I, 198 ) and that '... "obeying a rule" is a practice' (Wittgenstein 1953, \# I, 202). The confusion is the result of the two concepts of understanding (i.e. knowledge of $v s$. knowing how to go on). For all kinds of reasons, the ethnographer may not be willing to go on in a particular way (dictated by a practice). In a sense one could say she does not understand it, but it would be clearer to argue that though she may well understand it, she is not taking this particular route since for her that route does not make sense (cf. Smeyers 2006).

Being on the inside or outside is nicely captured by the contextual presupposition of telling the following joke, once told to me by a Jew during a Bar Mitzvah, a Jewish ritual performed in a synagogue. The joke goes as follows. God wanted to give a table in stone (detailing advice on how to lead one's life) to a particular group. When it was offered to the Arabs, they declined - you may recall the seventh commandment. Thus the French too expressed no interest given the sixth and the ninth commandments. So he turned to the Jews. One of them asked God how much it would cost. When He answered 'Nothing', the Jew said: 'Well, can I please have two of them then?' The point I want to make is that you have to be a Jew to be 'competent' to tell this joke and thus not reproachable for being a racist, expressing anti-Semitism or even xenophobia. It is not only striking to make such a joke about your own group (something the Jews are famous for: Freud, for instance, wrote about der Witz), it is moreover remarkable to tell such a joke during a religious ceremony and in a synagogue. This brings me to the issue of entitlement, in the case of the anecdote the entitlement to tell this joke, but also more generally, to say what it means 'to know how to go on'. In the absence of fixed rules which determine what and what does not count as belonging to a practice, it is only she who is on the inside who is entitled to legislate about the application of a rule, in other words, on the basis of belonging to a particular group. This points towards 'being acknowledged' as being entitled and thus to other notions such as conversion and initiation which make sense along these lines. Winch argues:

The notion of being committed by what I do now to doing something else in the future is identical in form with the connection between a definition and the subsequent use of the word defined .... It follows that I can only be committed in the future by what I do now if my present act is the application of a rule ... this is possible only where the act in question has a relation to a social context: this must be true even of the most private acts, if, that is, they are meaningful. (Winch 1958, 50) ${ }^{1}$

Evidently, this is not in terms of knowledge but of doing and being entitled to do so in the future. It goes without saying that at some point a practice ceases to exist. So it may be all right for the ritual of the State opening ceremony of the British Parliament no longer to demand from Black Rod, The Lord Chancellor, to walk backwards down the steps from the throne in the House of Lords after handing the speech over to the Monarch: at some point, we, who belong to a particular community, will say 
that a particular practice is no longer ours. It is about seeing the point of a particular action (cf. also Winch 1958, 55 ff., where he discusses Lewis Carroll's 'What the tortoise said to Achilles').

Not distinguishing between these two concepts of understanding lies at the basis of much nonsense that is written about the insider's and the outsider's perspective. Bridges' paper helps us to see why this is so. I am sure he understands what others do not, that is, at least if I have correctly and fairly represented his views. I am less happy though with his and others' use of the concept of 'negotiation of meaning' or, as in the synopsis, of the 'construction of understanding'. As it is clear that we find ourselves within a context that is meaningful, yet accepting no crude correspondence theory of truth (where meaning is exclusively defined in terms of reference) but a community of competent language users instead, there is no need to speak of 'construction of meaning'. Neither does it make sense to invoke 'negotiation', where we only want to point to what someone else 'sees', understands, gives meaning to (consistent with what makes sense to her). Of course, 'negotiation' can mean many things, it surely also is a 'family resemblance concept', but one should not cross the boundary of such a precise Wittgensteinian term and get lost in blurred usage.

Let me conclude by briefly recalling some interesting details of the 1990 movie by Jim Wilson and Kevin Costner featuring Kevin Costner as Lt. John J. Dunbar, referred to by the Indians as 'Dances With Wolves'. Dunbar tries to build a relationship with the wolf that follows him (which he names 'Two Socks' from the colouring of its front legs) as well as with his Indian neighbours, the Sioux. Though they are initially described to him as nothing but thieves and beggars, he learns otherwise, as they too change their mind about him 'who did not come to fight them'. Dunbar and Kicking Bird, a holy man, try to find a common language and Dunbar's efforts to build trust result in his no longer being suspected but respected up to the point where he is accepted as a full member of the tribe. Then he does not feel lonely anymore and when he becomes one of them he says 'he knows where he belongs'. There is a striking difference though between his understanding of the wolf that he befriends and who follows him but who is never fully at ease with him, and the way the soldier and the Sioux grow together. His relationship with these Indians is nourished by trying to find out 'how to go on', based on mutual trust. His knowledge of them, laid down in a journal, will eventually become crucial in the plot of the movie, as it is a blueprint for finding the Sioux after Fort Sedgwick (the desolate and deserted fort to which he was sent) is re-occupied by reinforcing Army troops. $\mathrm{He}$ is not trying to safeguard the journal keeping order to preserve what he came to understand, possibly to pass it on to someone else who is interested in the way of life of these Indians, but instead he needs to get hold of it to make sure that it does not fall into the hands of the Army. Though Dunbar is loyal to the wolf (who would not leave because he is 'faithful' to Dunbar and is, a result of this, to be shot by the soldiers), his solidarity with the Sioux goes so far that he is willing to give up what is most dear to him (i.e. being part of their tribe). When he returns to the winter camp, he realises that as a deserter and fugitive he will continue to draw the unwelcome attention of the Army and endanger the welfare of the tribe if he stays with them. In the face of protests from his Sioux friends he decides that he must leave them, saying he must speak to those who would listen. And when he does so, accompanied 
by his wife, 'Wind In His Hair', a Sioux, cries out that Dances With Wolves will always be his friend.

Dances With Wolves became someone to whom the other Sioux would listen. He became entitled to decide with them what needs to be done, i.e. how their way of life could be secured against the White Men. From being interested in their way of life, he became part of it. One could also say that he could not remain indifferent towards them. His 'knowledge of' developing into 'knowing how to go on' based on mutual respect (not as in the case of the wolf, where food and being attentive to their surroundings seem to be what kept them going on in a particular way). The movie is full of evocative images: for instance, when you exchange something (a jacket, a hat), both of the parties have to give up something for which they care, or the insight that on being confronted with a different way of life, one's own is threatened as well. The message it conveys to me for Bridges' paper points concerning educational research to the idea that though knowledge may be necessarily the beginning, it cannot leave us to indulge ourselves in the feeling of complacency that this is all we, as philosophers of education, have to acquire or achieve. Indeed, it pushes us in the direction that we have to make it our business to know how to go on (cf. Smeyers 2007). In that sense too, we cannot but necessarily be insiders. It cannot be a coincidence that Terry McLaughlin continually stressed the importance for education of a change of life.

\section{Note}

1. The latter part of this quotation highlights another point that is worth mentioning: Winch's discussion of a private rule of conduct. He argues that in order to make sense, to be meaningful for the author herself, others must at least, in principle, be able to understand it (Winch, 1958, 33).

\section{References}

Smeyers, P. 2006. 'What it makes sense to say'. Education, philosophy and Peter Winch on social science. Journal of Philosophy of Education 40: 463-85.

Smeyers, P. 2007. The invisible homogenization of educational research. On opening up the sphere of responsiveness. In Educational research: Networks and technologies, ed. P. Smeyers and M. Depaepe, 84-104. Dordrecht: Springer.

Winch, P. 1958. The idea of a social science and its relation to philosophy. London: Routledge \& Kegan Paul.

Wittgenstein, L. 1953. Philosophical investigations (Philosophische Untersuchungen, translated by G.E.M. Anscombe). Oxford: Basil Blackwell.

Wittgenstein, L. 1980. Culture and value (Vermischte Bemerkungen, edited by G.H. von Wright and translated by P. Winch). Oxford: Basil Blackwell. 